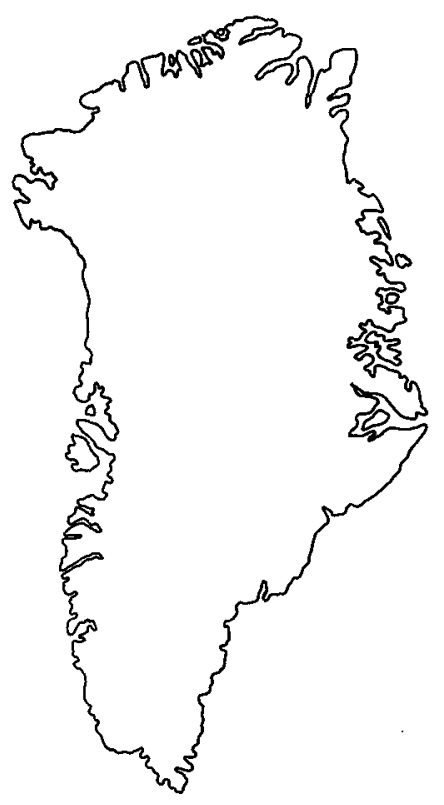

\title{
Silurian palynomorphs from the Chester Bjerg Formation, Hall Land, western North Greenland
}

\author{
Howard A. Armstrong \\ and Ken J. Dorning
}

\begin{abstract}
Silurian palynomorphs from a single sample from the Chester Bjerg Formation, near Halls Grav, Hall Land, western North Greenland are of Wenlock or possibly early Ludlow age. Graptolites from the same sequence indicate a Pridoli (latest Silurian) age. The strata in question are the youngest known pre-Innuitian orogeny deposits in North Greenland. Possible reworking of the palynomorphs in the turbidite sequence is discussed.
\end{abstract}

H. A. A., Department of Geology, The University, Newcastle upon Tyne NE1 7RU, U.K.

K. J. D., Pallab Research, 58 Robertson Road, Sheffield S6 $5 D X, U . K$.

The sequence at Halls Grav, Hall Land, western North Greenland (fig. 1) is of note in having yielded the youngest pre-deformation faunas yet known from the mainly Lower Palaeozoic sequence of the North Greenland trough. The faunas are of particular interest in the evolution of North Greenland in that they place a lower age constraint on the timing of the deformation which produced the North Greenland fold belt, a continuation of the Innuitian orogenic system of adjacent arctic Canada. Discussion in the literature (see Dawes \& Peel, this report) has suggested latest Silurian (Pridoli) or earliest Devonian ages for graptolite and vertebrate faunas collected from these sediments during Operation Grant Land 1965-66. The present examination of palynomorphs from the stratigraphically highest samples available represents an attempt to give a new dimension to this discussion.

\section{Palynomorphs}

Standard palynological techniques were employed to recover many moderately preserved acritarchs, and occasional chitinozoans and miospores from GGU 82738, a dark grey, brownish weathering, bioclastic limestone collected by P. R. Dawes at 'Observatory Bluff' (fig. 1). This sample is one of several from a c. $1 \mathrm{~m}$ thick bed of limestone which have yielded vertebrate remains after acetic acid digestion (Bendix-Almgreen \& Peel, 1974; BendixAlmgreen, 1976). Several similar beds of limestone or limestone breccia occur within the Rapp. Gronlands geol. Unders. 121, 97-103 (1984) 


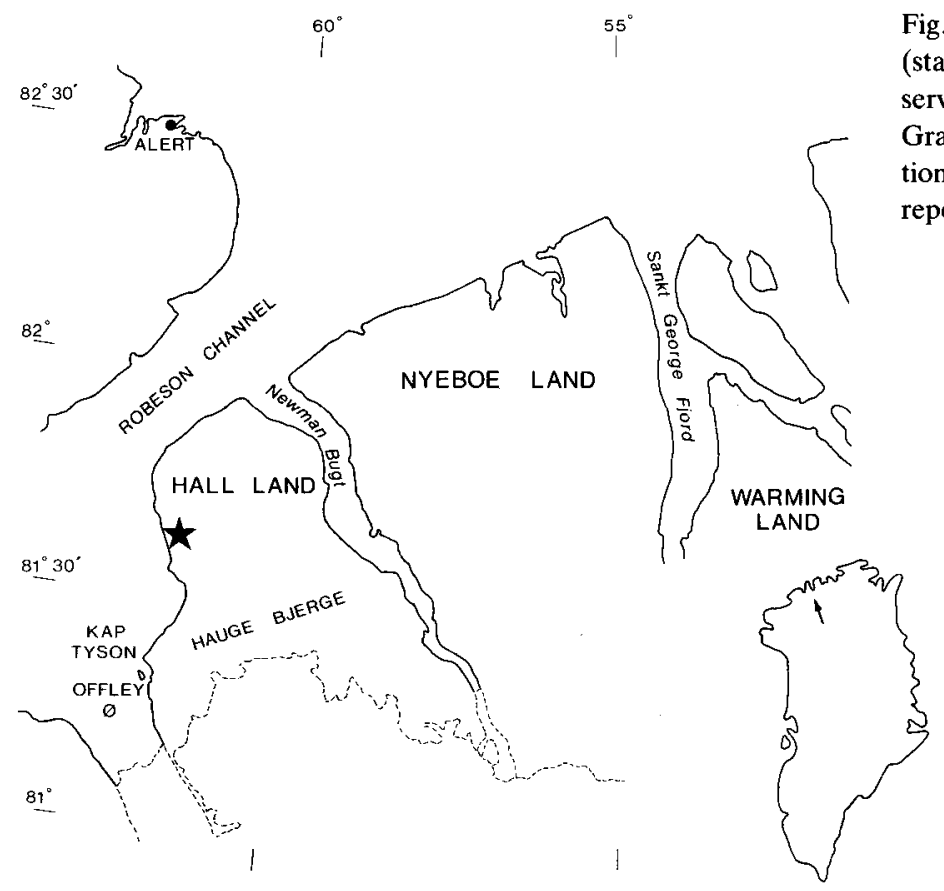

Fig. 1. Collection locality (star) for GGU 82738 at 'Observatory Bluff', near Halls Grav, Hall Land. This is section 2 of Dawes \& Peel (this report).

thin-bedded, monotonous sequence of grey laminated mudstones, calcareous siltstones and darker, fine-grained greywackes which Hurst \& Surlyk (1982) have subsequently assigned to the Chester Bjerg Formation. The acritarchs are brown in colour (Staplin Index 3) suggesting that the surrounding sediments have been heated to a maximum temperature of about $180^{\circ}$. The miospores (Ambitisporites dilutus (Hoffmeister) Richardson \& Lister, 1969) are dark brown. Chitinozoans are black and include species of Conochitina, Eisenackitina and Sphaerochitina.

Acritarchs:

Ammonidium waldronense (Tappan \& Loeblich) Dorning, 1981

Diexallophasis granulatispinosa (Downie) Hill, 1974

Diexallophasis sp.

Domasia limaciforme (Stockmans \& Williere) Cramer, 1970

Domasia trispinosa Downie, 1960

Leiosphaeridia $\mathrm{sp}$.

Micrhystridium sp.

Multiplicisphaeridium arbusculum Dorning, 1981

Oppilatala ramusculosa(Deflandre) Dorning, 1981

Salopidium granuliferum (Downie) Dorning, 1981

Tylotopalla wenlockia Dorning, 1981

Tylotopalla sp.

Veryhachium trispinosum (Eisenack) Cramer, 1964

Based on known acritarch ranges, particularly from sections in the Wenlock and Ludlow of the Shropshire type areas (Lister, 1970; Dorning, 1981), from Europe (Cramer, 1964, 
1970) and eastern North America (Cramer, 1970, 1979; Cramer \& Diez de Cramer, 1972), the presence of Ammonidium waldronense would indicate a Wenlock to early Ludlow age. Domasia trispinosa occurs commonly in the Llandovery-Wenlock boundary strata in the Welsh Borderland (Hill, 1974; Mabillard, 1981). Tylotopalla wenlockia ranges through the Wenlock, but is only rarely known from the lower Ludlow (Lister, 1970). Diexallophasis granulatispinosa was recorded from the lower Wenlock and older strata of the Welsh Borderland by Dorning (1981), while Salopidium granuliferum ranged from deposits of latest Llandovery to earliest Ludlow age. Oppilatala ramusculosa and Multiplicisphaeridium arbusculum both range from the Wenlock into the Ludlow in the Welsh Borderlands (Dorning, 1981).

The palynomorph assemblage therefore suggests a Wenlock or possibly early Ludlow age for this sample.

Discussion. Berry et al. (1974) referred graptolites from apparently lower in the strongly deformed sequence at Halls Grav to Monograptus sp. of $M$. transgrediens type, considered indicative of a Pridoli (late Silurian) age. A single specimen was identified as $M$. cf. $M$. aequabilis, suggestive of an earliest Devonian age. This graptolite has subsequently been redetermined by $\mathbf{H}$. Jaeger (in Surlyk, et al., 1980) as $M$. cf. $M$. transgrediens, probably of Pridoli age.

Bendix-Almgreen \& Peel (1974) and Bendix-Almgreen (1976) examined vertebrate remains from a limestone bed at 'Observatory Bluff', apparently higher in the sequence than the graptolites identified by Berry et al. (1974) from nearby inland cliffs. A general late Silurian - early Devonian age was indicated, readily reconcilable with the early Devonian age suggested by Berry et al. (1974). The vertebrates and associated fauna (see Dawes \& Peel, this report) were collected from the same suite of samples (GGU 82733-82738) as the sample processed here for palynomorphs. S. Turner (in Dawes \& Peel, this report) compared thelodonts from the vertebrate fauna with assemblages from the Downtonian (= Pridoli) of western Europe, which agrees well with the revised graptolite determinations of Jaeger.

The Wenlock or early Ludlow age suggested by the palynomorphs is not in good agreement with the Pridoli ages suggested by the thelodonts from the same sample or the graptolites from apparently stratigraphically older deposits. The discrepancy in age may result from 'atypical' ranges of the palynomorphs and other taxa, since the material at hand is restricted and no embracive study of the deposits in question has been undertaken. Alternatively, fossil assemblages from 'Observatory Bluff' may be wholly or partially derived, which is quite possible when the turbiditic nature of the Chester Bjerg Formation is taken into consideration (Hurst \& Surlyk, 1982). The palynomorphs, however, show no evidence in themselves of being a mixed assemblage; neither is there marked variation in colour or obvious abrasion. Solution of the problem clearly awaits better and more precisely located material.

Acknowledgements. John S. Peel suggested modifications to the manuscript which was prepared with the help of Miss E. Walton, Esben Glendal and Niels H. Larsen. 


\section{References}

Bendix-Almgreen, S. E. 1976: Palaeovertebrate faunas of Greenland. In Escher, A. \& Watt, W. S. (edit.) Geology of Greenland, 534-573. Copenhagen: Geol. Surv. Greenland.

Bendix-Almgreen, S. E. \& Peel, J. S. 1974: Early Devonian vertebrates, Hall Land, North Greenland. Rapp. Grønlands geol. Unders. 65, 13-16.

Berry, B. N. et al. 1974: Late Silurian and early Devonian graptolites from North Greenland. Rapp. Grønlands geol. Unders. 65, 11-13.

Cramer, F. H. 1964: Microplankton from three paleozoic formations in the province of Leon (NW Spain). Leidse Geol. Meded. 30, 253-361.

Cramer, F. H. 1970: Distribution of selected Silurian acritarchs. Rev. Espan. Micropaleont., num. extraord. 1-203.

Cramer, F. H. 1979: Lower Palaeozoic acritarchs. Palinologia 2, 17-159.

Cramer, F. H. \& Diez de Cramer, M. del C. R. 1972: North American Silurian palynofacies and their spacial arrangement: Acritarchs. Palaeontographica B, 138, 107-180.

Dawes, P. R. \& Peel, J. S. this report: Biostratigraphic reconnaissance in the Lower Palaeozoic of western North Greenland. Rapp. Grønlands geol. Unders. 121, 19-51.

Dorning, K. J. 1981: Silurian acritarchs from the type Wenlock and Ludlow of Shropshire, England. Rev. Palaeobot. Palynol. 34, 175-203.

Downie, C. 1960: Deunffia and Domasia, new genera of Hystrichospheres. Micropaleontology 6, 197202.

Hill, P. J. 1974: Stratigraphic palynology of acritarchs from the type area of the Llandovery and the Welsh Borderland. Rev. Palaeobot. Palynol. 18, 11-23.

Hurst, J. M. \& Surlyk, F. 1982: Stratigraphy of the Silurian turbidite sequence of North Greenland. Bull. Grønlands geol. Unders. 145, 121 pp.

Lister, T. R. 1970: The acritarchs and chitinozoa from the Wenlock and Ludlow Series of the Ludlow and Millichope areas, Shropshire. Palaeontogr. Soc. (Monogr.), Part 1, 1-100.

Mabillard, J. E. 1981: Micropalaeontology and correlation of the Llandovery-Wenlock boundary beds in Wales and the Welsh Borderlands. Unpubl. Ph.D. thesis, Univ. Nottingham, U.K.

Richardson, J. B. \& Lister, T. R. 1969: Upper Silurian and Lower Devonian spore assemblages from the Welsh Borderland and South Wales. Palaeontology 12, 201-252.

Surlyk, F., Hurst, J. M. \& Bjerreskov, M. 1980: First age-diagnostic fossils from the central part of the North Greenland foldbelt. Nature, Lond. 286, 800-803. 


\section{Plate 1}

All specimens are from GGU sample 82738. MGUH denotes specimens in the type series of the Geologisk Museum, Copenhagen. Slide number is followed by the England finder coordinates of each specimen; all $\times 1000$.

Fig. 1. Ambitisporites dilutus. 82738(2); V243; MGUH 16.532

Fig. 2. Oppilatala ramusculosa. 82738(2); U301; MGUH 16.533

Fig. 3. Ammonidium waldronense. 82738(2); R381; MGUH 16.534

Fig. 4. Diexallophasis sp. 82738(2); P303; MGUH 16.535

Fig. 5. Tylotopalla sp. 82738(2); H421; MGUH 16.536

Fig. 6. Salopidium granuliferum. 82738(2); T290; MGUH 16.537

Fig. 7. Multiplicisphaeridium arbusculum. 82738(2); C403; MGUH 16.538

Fig. 8. Domasia trispinosa. 82738(3); K361; MGUH 16.539

Fig. 9. Ammonidium waldronense. 82738(3); W470; MGUH 16.540

Fig. 10. Domasia limaciforme. 82738(3); A310; MGUH 16.541

Fig. 11. Tylotopalla wenlockia. 82738(2); S432; MGUH 16.542

Fig. 12. Diexallophasis sp. 82738(2); P303; MGUH 16.543 


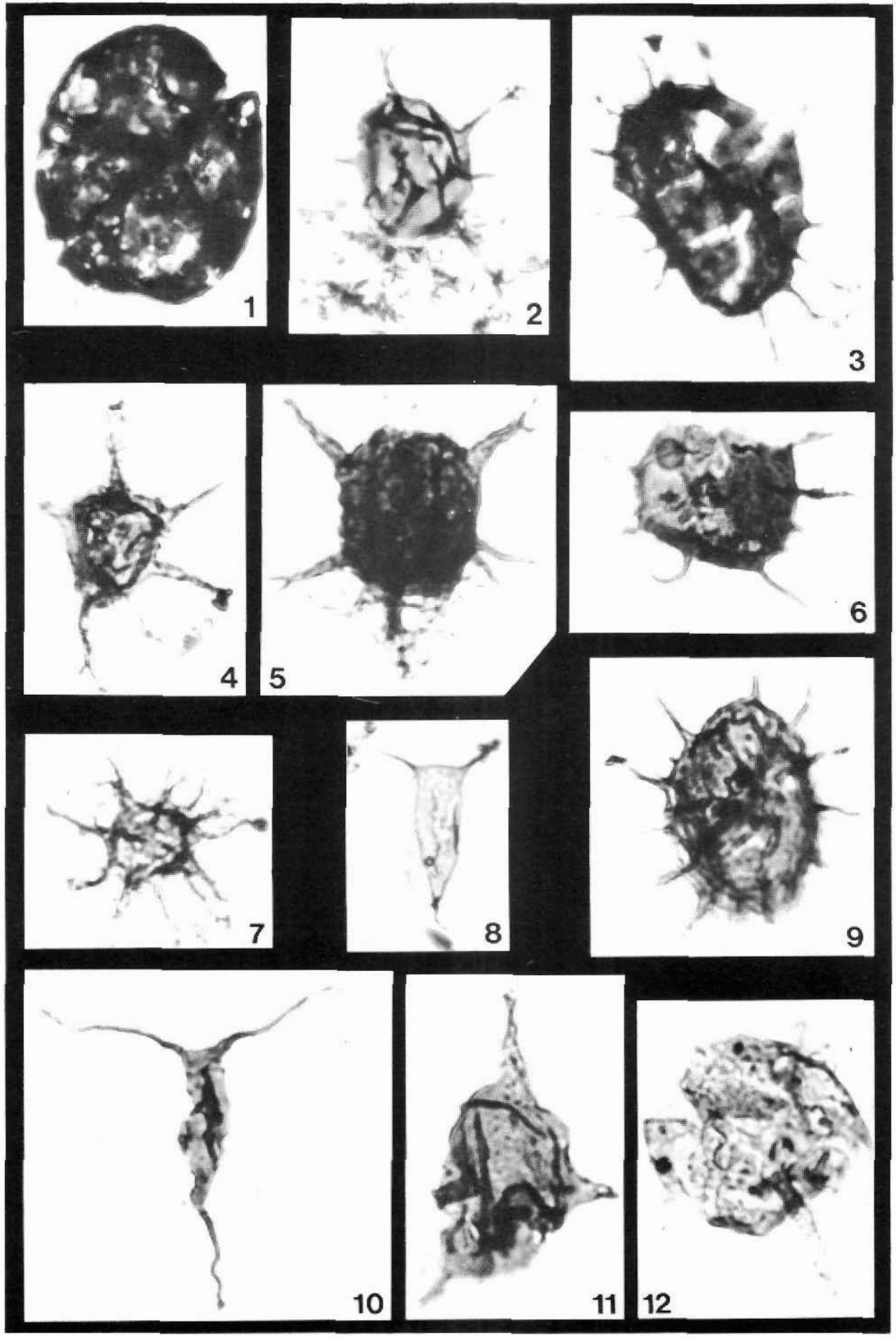

